\title{
Building local fashion brand equity for young consumers
}

\author{
Mega Melina Dewi, Dudi Anandya, \& Christina Rahardja Honantha \\ University of Surabaya, Surabaya, Indonesia
}

\begin{abstract}
The purpose of this study was to examine the effect of brand awareness, perceived quality of the brand, brand association, brand loyalty, and brand image on the brand equity of local fashion brand among young consumers in Surabaya. Data from 215 undergraduate students were analyzed using Structural Equation Model (SEM) via the Statistical Package for Social Sciences computer program version 18 and Lisrel version 8.7. Respondents were randomly drawn from the full time students of various universities in Surabaya city, Indonesia. Based on test results, it was found that all variables have positive and significant impact on brand equity. Thus, all hypotheses are supported. In this study, brand association predominantly affects brand equity. The implication of these results would help the company as the manufacturer to formulate strategies to enhance their brand equity in order to obtain competitive advantage and market expansion, especially through social media and e WOM.
\end{abstract}

Keywords: brand equity, brand equity dimensions, young consumers, local brand

\section{INTRODUCTION}

A Brand is the most valuable asset for all companies because it becomes one of the considerations for consumers in making product selection (Sasmita \& Suki 2015). Brand equity takes place when consumers have a tendency to believe in a particular brand over another, demonstrated by consumer loyalty and a desire to pay a premium for a brand (Lassar et al.

1995). Companies with high brand equity gain competitive advantage and enjoy opportunities to expand success, increase resilience to competitors' promotional pressures, and create barriers for competitors to enter the market (Severi \& Ling 2013).

Previous research on brand (Luijten \& Reijnders 2009, Chan et al. 2013, Tantiseneepong et al. 2012, Thwaites et al. 2012) conducted in non-Asian countries so the results were less applicable in Asian countries (Sasmita \& Suki 2015). Other research on brand equity (Tolba 2011, Emari et al. 2012, Faircloth et al. 2001, Netemeyer et al. 2004, Pouromid \& Iranzadeh 2012) only examined some of the variables associated with brand equity.

This research tries to close the research gap from some previous research which only examines the influence of some antecedents of brand equity.
Tolba (2011) examines brand awareness, perceived quality, brand loyalty; Emari et al. 2012 examines brand association and brand loyalty; Faircloth et al. 2001 only uses brand association; Netemeyer et al. 2004 uses perceived quality; Pouromid \& Iranzadeh 2012 evaluate brand awareness, brand association, and perceived quality, Sasmita \& Suki 2015 also examine only 3 antecedents (brand association, brand loyalty, and brand awareness). This research used four main elements according to Aaker (1991), and also adds brand image as one dimension.

This research also expanded the generalization of brand equity model from Aaker (1991) by using the object of fashion brand (Erigo). This brand is very popular among Indonesian youth, this brand is only marketed online and build their brand equity through social media and e-WOM.

Based on the above explanation, this study aims to examine how the influence of brand awareness, perceived quality of the brand, brand association, brand loyalty, and brand image towards online fashion brand equity. 


\section{LITERATURE REVIEW}

Brand equity is one of the most essential and frequently discussed marketing concepts in the past 10 years (Emari et al. 2012). According to Aaker (1991), brand equity is defined as a set of brand assets and liabilities linked to a brand, its name and symbol, that add to or subtract from the value provided by a product or service to a firm and / or to that firm's customers. While other definition by Keller (1993), shows that brand equity is "the differential effect of brand knowledge on consumer response to the marketing of the brand".

In this research, brand equity refers to Aaker (1991), especially in the context of consumer-based brand equity. The measurement carried out through four main elements, which are: 1) brand awareness; 2) perceived quality of brand; 3 ) brand association; and 4) brand loyalty, (Yoo \& Donthu 2001, Washburn \& Plank 2002). Other proprietary brand asset elements were not used because according to Shrestha (2010), they are not suitable for measuring consumer-based brand equity.

Brand awareness is defined as "the ability of a potential buyer to recognize or recall that a brand is a member of a certain product category" (Aaker 1991). Pouromid \& Iranzadeh (2012) stated that brand awareness is said to have a direct effect on brand equity. Therefore, the first hypothesis in this research is:

$\mathrm{H} 1$ : Brand awareness increases brand equity.

According to Aaker (1991), perceived quality of brand is "the customer's perception of the overall quality or superiority of a product or service with respect to its intended purpose, relative to alternatives". Zeithaml (1988) and Erenkol \& Duygun (2010) explained that product quality differs from perceived quality because perceived quality is a subjective judgment of consumers about the product.

Perceived quality of brand arises not from the detailed knowledge of a product brand, but from a consumer's perception of its quality. Yoo et al. (2000) stated that brand equity will increase with the help of a positive perceived quality promotion. Thus we propose second hypothesis:

$\mathrm{H} 2$ : Perceived quality will have positive influence on brand equity.

According to Aaker (1991) the brand association is "anything linked in memory to a brand". Brand association has a function to help the process of information formation, differentiation, as a reason to buy, can create a positive attitude or feeling, and as a foundation for product expansion (Aaker 1991).

Brand association serves as a tool for gathering information to manage brand differentiation and brand extension (Osselaer \& Janiszewski 2001). The higher the brand association of the product, the more consumers will remember and be loyal to the brand (Sasmita \& Suki 2015). Previous research by Pouromid \& Iranzadeh (2012) also indicates a positive and significant relationship between brand association and brand equity.

H3: Brand association has positive influence on brand equity.

According to Aaker (1991), brand loyalty is "a measure of the attachment that a customer has to a brand". This indicates the tendency of the customers to switch to another brand when there is a change in product attributes.

Rangkuti (2004) also stated that loyalty is the core of brand equity. If brand loyalty increases, then the customer's vulnerability to a competitor's product can be reduced. Customers develop brand loyalty by creating positive brand equity output that raises brand preference over other brands (Atilgan et al. 2005, Severi \& Ling 2013). Our fourth hypothesis is:

H4: Brand loyalty has positive influence on brand equity.

According to Aaker (1991), brand image is "a set of association, usually organized in some meaningful way". According to Keller (1993) brand image is "perception about a brand as reflected by the brand association held in customer memory".

Keller (1993) stated that to build brand equity, it takes a well-known brand name and positive brand image. Research from Faircloth et al. (2001) show that brand image is a predictor of brand equity, whereas image can be improved the brand equity will also increase.

H5: Brand image has positive influence on brand equity.

\section{RESEARCH METHOD}

The operational definition of brand equity referred to Sasmita \& Suki 2015, while perceived quality was derived from Tong \& Hawley (2009), for brand awareness, brand association, brand loyalty, and our brand image referred to Severi \& Ling 2013. All measurements used 5 points Likert scale.

The research data was obtained from 215 respondents with purposive sampling technique. Characteristics of respondents are students who own smartphone, active in social media and have bought online fashion products in the past year. Data processing used Structural Equation Modeling with LISREL software. 


\section{RESULT AND DISCUSSION}

Validity and reliability test results have shown a valid and reliable value in which all items can be used. The measurement model shows GFI of 0.89 with all loading factors above 0.5 .

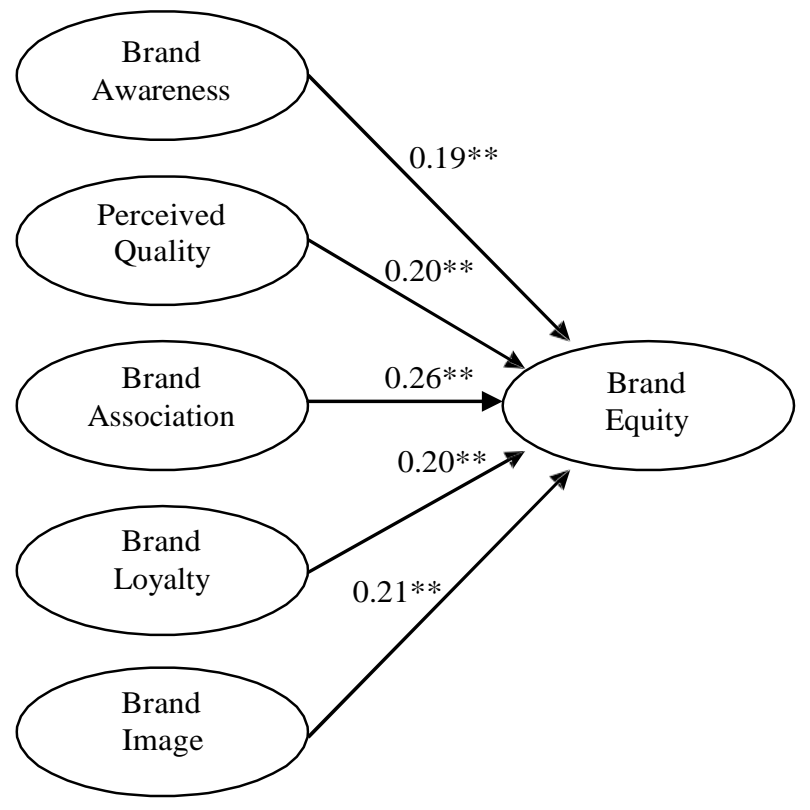

** Significance at 0.01 level

Figure 1. The Structural Model Result (Standardize estimate)

The structural model shows GFI of 0.89 RMSEA 0.048 and TLI 0.99 . From the 5 hypotheses proposed, they all show a level of significance below $5 \%$ so that all hypotheses are supported.

These results indicate that young consumers are also building all these brand equity antecedents through social media. Successful online brands that build brand awareness, brand association, perceived quality, brand loyalty and a good brand image will enjoy high brand equity. The interesting thing is that the brand in this research builds brand equity through below the line activities, by utilizing the community in social media and e-WOM.

\section{CONCLUSION}

This study extends the generalizations of the former model (Aaker 1991, Sasmita \& Suki 2015). Brand equity can also be built through the social media community and using e-Wom. Brand association dimensions have the most influence in shaping brand equity, while brand awareness is the dimension that has the weakest effect. This could be due to the brand used in this study has been very popular among young social media users, so that association is the more dominant. This research can be expanded by trying on non-fashion products in cyberspace.

\section{REFERENCES}

Aaker, D. A. 1991. Managing Brand Equity: Capitalizing on the Value of a Brand Name New York: The Free Press.

Atilgan, E., S. Aksoy \& S. Akinci. 2005. Determinants of the brand equity: A verification approach in the beverage industry in Turkey. Marketing Intelligence \& Planning 23 (3): 237-248.

Chan, Kara, Y. Leung Ng, \& E.K. Luk. 2013, Impact of celebrity endorsement in advertising on brand image among Chinese adolescents. Young Consumers 14(2): 167179.

Emari, H., A. Jafari, \& M. Mogaddam. 2012. The mediatory impact of brand loyalty and brand image on brand equity. African Journal of Business Management. 6(17): 55925701.

Erenkol, H., A. Degermen \& A. Duygun. 2010. Customer's perceived brand equity and a research on the Customers of Bellona which is a Turkish furniture brand. The Journal of American Academy of Business, Cambridge 16 (1): 93109.

Faircloth, J.B., L.M. Capella, \& B.L. Alford. 2001. The effect of brand attitude and brand image on brand equity. Journal of Marketing Theory and Practice 9 (3): 61-75.

Keller, K.L. 1993. Conceptualizing, measuring, and managing customer-based brand equity. Journal of marketing 57(1): 1- 22.

Lassar, W., B. Mittal \& A. Sharma. 1995. Measuring customerbased brand equity. Journal of Consumer Marketing 12(4): 11 19.

Luijten, T., \& W. Reijnders. 2009. The development of store brands and the store as a brand in supermarkets in the Netherlands. The International Review of Retail, Distribution, and Consumer Research 19(1): 45-58.

Netemeyer, R.G., B. Krishnan, C. Pullig, G. Wang, M. Yagci, D. Dean, J. Ricks, \& F. Wirth. 2004. Developing and Validating Measures of Facets of Customer-Based Brand Equity. Journal of Business Research 57(1): 209-224.

Osselaer, Stijn M. J. van \& Chris Janiszewski. 2001. Two ways of Learning Brand Associations. Journal of Consumer Research. 28 (2): 202-223.

Pouromid, B. \& S. Iranzadeh. 2012. The evaluation of the factors affects on the brand equity of Pars Khazar household appliances based on the vision of female consumers. Middle- East Journal of Scientific Research. 12(8): 10501055.

Rangkuti, F. 2004. The power of brands: Teknik Mengelola

Brand Equity and Strategi Pengembangan Merek. Jakarta: PT. Gramedia Pustaka Utama.

Sasmita, J. \& N.M. Suki. 2015. Young consumer's insights on brand equity: effects of brand association, brand loyalty, brand awareness, and brand image. Journal Of Retail \& Distribution Management 43(3): 276-292.

Severi, E. \& K.C. Ling. 2013. The mediating effects of Brand Association, Brand Loyalty, Brand Image, and Perceived Quality on Brand Equity, Asian Social Science 9(3): 125137. 
Shrestha, S.K. 2010. Perspective on brand equity and its dimensions. Ganeshman Darpan 3(3): 52-60.

Tantiseneepong, N., M. Gorton \& J. White. 2012. Evaluating responses to celebrity endorsements using projective techniques, Qualitative Market Research: An International Journal 15(1): 57-69.

Thwaites, Des, Ben Lowe, L.L. Monkhouse, \& Bradley R. Barnes. 2012 The impact of negative publicity on celebrity Ad-endorsements, Psychology \& Marketing 29(9): 663-673.

Tolba, A.H. 2011 The impact of distribution intensity on brand

preference and brand loyalty, International Journal of Marketing Studies 3(3): 56-66.

Tong, Xiao., \& J.M. Hawley. 2009. Creating brand equity in the Chinese Clothing Market: the effect of selected marketing activities on brand equity dimensions. Journal of Fashion Marketing and Management: An International Journal 14(3): 143-154.

Washburn, J.H. \& R.E. Plank. 2002. Measuring brand equity: an evaluation of a consumer-based brand equity scale. Journal of Marketing Theory and Practice 10(1): 46-62.

Yoo, B. \& N. Donthu. 2001. Developing and validating a multidimensional consumer-based brand equity scale. Journal of Business Research 52(1): 1-14.

Yoo, B., N. Donthu, \& S. Lee. 2000. An examination of selected marketing mix elements and brand equity. Journal of Academy of Marketing Science 28(2): 195-211.

Zeithaml, V.A. 1988. Consumer perceptions of price, quality, and value: a means-end model and synthesis of evidence. Journal of Marketing 52(2): 2-22. 